\title{
Identification of proteins that interact with the UL24 protein of herpes simplex virus 1
}

\author{
L Bertrand ${ }^{*}$, A Pearson \\ From Institut Pasteur International Network Annual Scientific Meeting \\ Hong Kong. 22-23 November 2010
}

Infection with herpes simplex virus 1 (HSV-1) typically results in the formation of cold sores; however, in individuals with a compromised immune system the infection can be severe. The virus life cycle is characterized by two distinct phases: a lytic replication phase occurring in mucous membranes, and a latent state that is established in neurons of the trigeminal ganglia.

The UL24 protein of HSV-1 is implicated in both the lytic and latent phases of infection. Infection with a UL24-deficient virus in vitro results in reduced viral yields and the formation of syncytial plaques, where the plasma membranes of infected cells fuse together. In vivo, the absence of UL24 results in reduced viral titers and a drastic reduction in viral reactivation $e x$ vivo. Previously, we showed that UL24 is both necessary and sufficient to induce the redistribution of the nucleolar protein nucleolin. The UL24 protein contains 269 amino acids and is expressed late in the virus life cycle. A bioinformatics study identified an endonuclease motif within the conserved $\mathrm{N}$-terminal portion of the protein; however, its function remains to be demonstrated. Although several roles have been attributed to UL24, the mechanisms involved are unknown.

We hypothesized that UL24 functions, at least in part, through protein-protein interactions. To investigate this possibility, we used a virus that expresses UL24 with a hemagglutinin (HA) tag fused to its N-terminus, vHAUL24. Lysates from infected cells were harvested, and fractionated on glycerol gradients. We found that UL24 was present in fractions corresponding to a much higher molecular mass than would be expected for UL24 alone, suggesting an association of UL24 with cellular or viral proteins during infection. To isolate potential UL24binding proteins, we performed immunoprecipitations on fractions containing HA-UL24, using antibodies

$\overline{\text { INRS-Institut Armand Frappier, 531, Blvd. Des Prairies, Laval, Quebec, Canada }}$ directed against the HA epitope. Immunoprecipitated proteins were resolved by denaturing polyacrylamide gel electrophoresis. Silver staining of the gel enabled the detection of proteins that appeared to specifically coprecipitate with HA-UL24. Candidate binding proteins will be identified by mass spectrometry. The identification of UL24-interacting partners will contribute to a better understanding of the roles of UL24 in different steps of the virus life cycle.

Published: 10 January 2011

doi:10.1186/1753-6561-5-S1-P101

Cite this article as: Bertrand and Pearson: Identification of proteins that interact with the UL24 protein of herpes simplex virus 1. BMC Proceedings 2011 5(Suppl 1):P101.

Submit your next manuscript to BioMed Central and take full advantage of:

- Convenient online submission

- Thorough peer review

- No space constraints or color figure charges

- Immediate publication on acceptance

- Inclusion in PubMed, CAS, Scopus and Google Scholar

- Research which is freely available for redistribution 